\section{Primary adhalinopathy: a common cause of autosomal recessive muscular dystrophy of variable severity}

F. Piccolo et al.

Nature Genetics 10, 243-245 (1995)

The first full sentence on page 245 should read "We conclude that primary adhalinopathies are a significiant cause of autosomal recessive myopathies and are geographically widespread."

\section{A teratologic suppressor role for $p 53$ in benzo[a]pyrene-treated transgenic p53- deficient mice}

Christopher J. Nicol, Maureen L. Harrison, Rebecca R. Laposa,

Inga L. Gimelshtein \& Peter G. Wells

Nature Genetics 10, 181-187 (1995)

An old version of Figure 3 was inadvertantly printed. The correct version is shown below.

\section{EMBRYOPATHY (\%)}

\section{MATERNAL GENOTYPE}

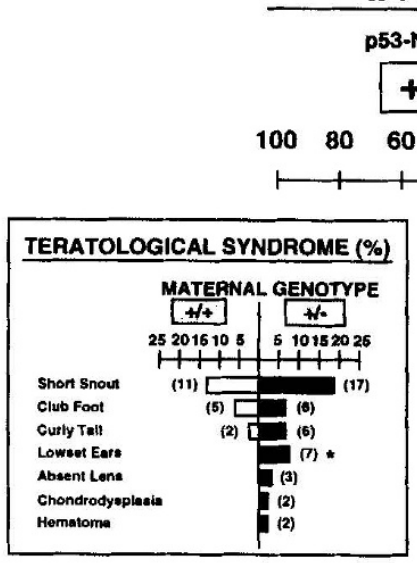

(83)

(83)

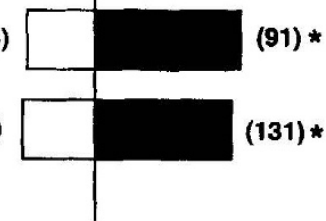

\section{High resolution DNA Fiber-fish on yeast artificial chromosomes: direct visualization of DNA replication}

Carla Rosenberg ${ }^{3}$, Ralph J. Florijn ${ }^{2}$, Frans M. Van De Rijke', Lau A.J. Blonden', Ton K. Raap ${ }^{2}$, Gert-Jan B. Van Ommen' ${ }^{1}$ \& Johan T. Den Dunnen ${ }^{1}$

Nature Genetics 10, 477-479 (1995)

The address list was ommitted. The list is shown below.

'MGC-Department of Human Genetics and ${ }^{2}$ Department of Cytochemistry and Cytometry, Leiden University, Wassenaarseweg 72, 3333 AL LEIDEN, The Netherlands

${ }^{3}$ Department of Biology, Universidade de São Paulo, Brazil

Correspondence should be addressed to J.T.D.D.

\section{APOE*4-associated Alzheimer's disease risk is modified by $\alpha 1$-antichymotrypsin polymorphism}

M. Ilyas Kamboh', Dharambir K. Sanghera', Robert E. Ferrell' \& Steven T. DeKosky ${ }^{2}$

Nature Genetics 10, 486-488 (1995)

The address list was ommitted. The list is shown below.

'Department of Human Genetics, Graduate School of Public Health, 'Departments of Psychiatry and Neurology and the Alzheimer's Disease Research Center, Western Psychiatric Institute and Clinic, University of Pittsburgh, Pittsburgh, Pennsylvania 15261, USA

Correspondence should be addressed to M.I.K.

\section{correction}

\title{
retraction
}

\section{Ceruloplasmin gene defect associated with epilepsy in EL mice}

Positional cloning moves from perditional

Francis S. Collins

Nature Genetics 9, 347-350 (1995)

In Table 2, the affected proteins in Charcot-Marie-Tooth disease types $1 \mathrm{~A}$ and $\mathrm{IB}$ were inadvertantly transposed. The correct listing should be as follows:

\section{Disease}

Charcot-Marie-Tooth disease type $1 \mathrm{~A}$ Charcot-Marie-Tooth disease type $1 \mathrm{~B}$
Affected protein

Peripheral myelin protein 22 Myelin protein zero $\left(P_{0}\right)$
Caroline E. Garey, Alexander L. Schwarzman, Matthew L. Rise \& Thomas N. Seyfried

Nature Genetics 6, 426-431 (1994)

It has recently come to our attention that serious inconsistencies occurred in data presentation that may be of sufficient magnitude to render some conclusions of the paper untenable. These problems are presently under further investigation in our laboratory. We therefore request that the paper be retracted from the scientific literature and apologize for all inconveniencies related to this infortunate situation. 